International Journal of Linguistics, Literature and Translation (IJLLT)

ISSN: 2617-0299 (Online); ISSN: 2708-0099 (Print)

DOI: $10.32996 / \mathrm{jjllt}$

Journal Homepage: www.al-kindipublisher.com/index.php/ijllt

\title{
On the Role of Verbal Particles in Bridging Tense Gap in English-Arabic/ Arabic-English
}

Translation

Younes Zhiri

ENS- Moulay Ismail University, Meknes, Morocco

SCALEC (Research Lab-ENS, UMI)

Corresponding Author: Younes Zhiri, E-mail: y.zhiri@umi.ac.ma

\section{ARTICLE INFORMATION}

Received: November 08, 2020

Accepted: December 10, 2020

Volume: 3

Issue: 12

DOI: $10.32996 /$ ijllt.2020.3.12.23

\section{KEYWORDS}

Tense, aspect, translation, verbal particles, discourse

\section{ABSTRACT}

Translating some grammatical forms such as temporal/event structures accurately across languages (as the case with English and Standard Arabic) is not easy to achieve as languages have different systems to refer to tense and aspect. Grammatical forms communicate meaning and sometimes this meaning can be lost in translation due to the translator's lack of mastery of both the source and the target languages, or at least one of them. Thus, event structures need to be carefully tackled in translation, and the translator, especially novice ones, need to develop a full understanding of the mechanisms that govern the use of such structures in the languages they are dealing with. Most importantly, they must be aware of the gaps that exist between those languages. In the light of this, the present paper sheds more light on the dissimilarities that exist between English and Standard Arabic as far as tense and aspect are concerned. The study highlights the gaps, and it shows that these gaps can be bridged if more importance is given to discourse clues and verbal particles mainly in the Arabic language.

\section{Introduction}

The way actions/events are expressed and represented grammatically in discourse differs from one language to another. Though there are similarities among languages, each language remains unique in terms of its grammar, let alone its temporal/tense system. Some languages have more grammatical categories for tense and aspect such as the case of English (with 12 basic tense-aspect forms), others have a more compact system like Standard Arabic -a language with only two aspectual oppositions: the perfect [al-ma:d`i الماضي] (originally refers to completed actions) and the imperfect [al-muda:ri؟ ] المضارع (originally refers to incomplete actions). Yet, this system, which is usually described as a simplified one does not seem so when studied closely and carefully. Here comes the importance of research in explaining and investigating things for a better understanding and/or use.

Translating across English and Standard Arabic regarding the area of tense and aspect might be challenging and risky, especially for unprofessional translators. In other words, meaning can be lost in translation if the translator fails to select the most appropriate equivalent form in the TL. The translator, as stated previously, is required to possess a thorough grammatical knowledge about the two languages at hand. Unfortunately, several translators seem to lack this quality. As a result, they usually resort to simple forms and structures to communicate their message; the matter that might often lead to a change in the communicated message that only professionals or people with a high command of the language are capable of recognizing. Thus, our objective, in the present study, is to show that equivalences in temporal/ event statements and structures do exist between English and Standard Arabic though these two languages are different in terms of the way this system is expressed. As the system is different, the means by which the various temporal/event structures are expressed are also different in each language. The present paper, then, addresses these differences with much focus on the sorts of means used in Standard Arabic to communicate the same or almost the same message as the one indicated by similar structures in the English language. To achieve this, we will be:

K C AL-KINDI CENTER
$\mathbf{R}$ D DOR RESEARCH AND
Your gateway to world-closs research
Published by Al-KindiCenter for Research and Development. Copyright (c) the author(s). This is an open access article under CC BY license (https://creativecommons.org/licenses/by/4.0/) 
1) Comparing, briefly, the tense-aspect systems of English and Arabic with much focus on how the Arabic system works,

2) Shedding more light on verbal particles in Arabic and the role they play in communicating the different meanings as well as their role in bridging the tense gap in translation between English and Arabic,

3) Presenting, supported by a variety of examples, a detailed synopsis about the possible Arabic translation of the 12 English tenses/aspects.

\section{Literature review}

\subsection{Translation}

Translation is a complex activity about which a lot has been written. Earlier, Nida and Taber (1982: 12) define it as the act of "reproducing in the receptor language the closest natural equivalent of the source language message, first in terms of meaning and second in terms of style". In contemporary research, Malmkjær (2012: abstract) defines it as an activity whose objective is to convey the same meaning/s across languages. He claims that there are, in fact, no exact translations as there is no correspondence between languages; yet, translation is always possible at some level. Translation then involves looking for lexical, grammatical, stylistic, rhetorical equivalences between the SL and the TL in order to communicate the message conveniently. However, what makes translation a difficult task is cultural variance and linguistic dissimilarities among languages. Thus, for a text to be successfully translated, the translator needs to have a full command of the language they are dealing with as well as a familiarity with the cultures involved.

The question of equivalence is a central one in the translation domain. Baker (1992: 5) lists five levels of equivalence: equivalence at word level, equivalence above word level, grammatical equivalence, textual equivalence, and pragmatic equivalence. Being the focus in this paper, grammatical equivalence is sometimes hard to achieve by translators, especially novice ones as there are plenty of structural dissimilarities among languages, especially distant ones. Baker (1992: 5) specifies five grammatical structures that usually create problems in translation. These involve Number, Gender, Person, Tense, and Voice. Such structures are difficult to translate because their grammatical and functional use differs from a language to another. Tense, for instance, is a complex grammatical component because not all languages have grammatical tense or tense markings. Some languages have explicit tense-aspect forms such as the case with English. Others have only aspect forms rather than tense such as Arabic. Additionally, the ways temporal relations are expressed vary from one language to another. Thus, translating event structures might be very risky if the translator is unaware of those dissimilarities we have been discussing so far. Therefore, the translator should be well versed in comparative grammar for effective rendering of the message from the SL to the TL.

Some studies have shown that the translation of grammatical structures such as Tense usually results in a failure to communicate the intended meaning. In their study, in which they focused on the translation of William Faulkner's novel "The Sound and the Fury" and its Persian equivalent, Ghassemi and Maghsoudi (2015: 29) discuss how tense changes in the translation from English to Persian and that this change leads to a change in meaning as well. Similarly, Zhiri (2014), in a study about the translation of some structures from English into Arabic and vice-versa, observed that student translators usually opt for the simplistic forms in each language such as overusing the simple present and the simple past forms in English and the bare perfect and the bare imperfect forms in Arabic in contexts that require the use of more complex forms in both languages. Therefore, such studies among others show that due to one reason or another translating event structures can sometimes be problematic.

\subsection{Tense and aspect in English and Arabic}

The literature distinguishes between tense and aspect as two grammatical interrelated concepts. On one hand, tense refers to how events are visualized in sequential time points one following the other (Downing and Locke, 1992: 30). In some sense, tense is the representation of time in language by the means of verb forms and verb endings. On the other hand, aspect should be seen as "different ways of viewing the internal temporal constituency of a situation" (Comrie, 1976: 3). Aspect in this sense involves localizing event situations in a time scale with regard to their completion or incompletion. Nida (1964: 198-9) indicates that while tense marks the relative time of events, aspect defines the nature of the action. Aspect, in its broader sense, divides into perfective and imperfective. This latter divides the habitual and the progressive aspects. In addition to describing the nature of the actions (complete or incomplete), aspect also indicates time. Having this in mind, let us explore how these two grammatical notions are displayed in both English and Arabic.

\subsubsection{Tense in English}

English is an example of a language with multiple tense-aspect forms. Actions in English are expressed using tense (past, present, and future) and aspect (simple/zero, progressive, perfect, and perfect progressive). These four aspects mark the verb with the same effect whether the action is in the past, present, or future. Aspect is usually realized by the combination 
of verbs, auxiliary verbs, and participles. Most importantly, each tense-aspect combination in English is used to refer to a specific time and context of use. Figure 1 below illustrates how the tense-aspect system is usually presented in the teachinglearning materials.

$\left(\begin{array}{l}\text { Past time } \\ \text { - Simple past } \\ \text { - Past progressive } \\ \text { - Past perfect } \\ \text { - Past perfect progressive }\end{array}\right)\left(\begin{array}{l}\text { Present time } \\ \text { - Simple present } \\ \text { - Present progressive } \\ \text { - Present perfect } \\ \text { - Present perfect progressive }\end{array}\right)\left(\begin{array}{l}\text { Future time } \\ \text { - Simple future } \\ \text { - Future progressive } \\ \text { - Future perfect } \\ \text { - Future perfect progressive }\end{array}\right)$

Figure 1: The English tense-aspect system

\subsubsection{Tense in Arabic}

Tense in Standard Arabic is so complex to understand. First, there is the traditional viewpoint that explained/investigated tense through the verb forms. These forms are devised by old grammarians on the basis of [tafৎila:t تفعيلات] (the three possible shapes that verbs take in relation to time). In his Al-Kitab, Sibawayh c. 760-796, one of the Persian leading grammarians in his time, stated that there are three forms of the Arabic verb: one signaling the past time (al-ma: $d^{\varsigma} \mathrm{i}:$ ), the other indicating the present or the future (al-mud'a:riৎ), and the third expressing commands (al-Pamr) (Gadalla, 2006: 52). This view, as we notice, was established upon the universal distinction of the absolute time division (past, present, and future). However, this traditional view seems to associate tense/ time with the verb form only as it excludes the other grammatical elements as well as the discourse clues that also express time and aspect in Arabic. This traditional viewpoint, in fact, has been criticized for mixing elements of tense and aspect together such as using the Arabic perfect form to refer to the past tense and the imperfect form to refer to both the present and the future.

The modern / contemporary viewpoint considers tense in Arabic to be inexplicit and unstable as it moves in discourse. In simple terms, the verb form in Arabic does not really express tense, but it indicates aspect instead. The same form (the perfect for instance) may indicate past, present, and future depending on the context of its occurrence as well as the clues/words that occur with. Hawamid (2016: 11) says that the form might be originally a past form, but its use in context may indicate present or future. It is the context that usually provides clues for understanding the tense at hand. Similarly, Bakri (2001: 76) claims that we do not really know whether a form like / jaf̧al يفعل/ refers to the present time or to the past time. When used without particles, the form / jaf̧al يفعل / indicates present (also when used with adverbials such as the word now). When used with particles, it refers either to future or to the past (depending on whether the particle precedes or follows it). This explanation was also provided before by DeCaen (1996) who considers Standard Arabic to be one of the tenseless languages since it consists of no overt tense markings. DeCaen (1996) further argues that Eventualities in Arabic are not expressed by the means of tenses, but by other language mechanisms such as adverbials, aspectual markings, prepositional phrases, and discourse anaphora. In the same vein, [السامرائي]A-ssamrai (1983: 24) also claims that verbal distinctions in Arabic are made upon aspect not tense, and it is the context that determines this latter. Based on those explanations, it is clear that verb forms in Arabic need careful attention as they are ambiguous.

Some Arab researchers who adopt the contemporary viewpoint shed light on the role of verbal particles in Arabic. Such researchers highlight the fact that particles provide more information about the time and the nature of the action. Besides, particles are capable of producing more complex time/ aspect distinctions along with the basic ones expressed by the means of /taffila:t التفعيلات/. In fact, there is a variety of verbal particles in Standard Arabic, and each communicates a specific

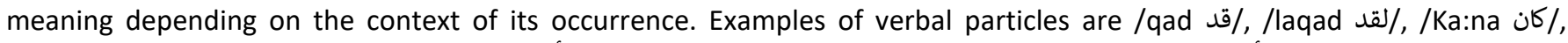

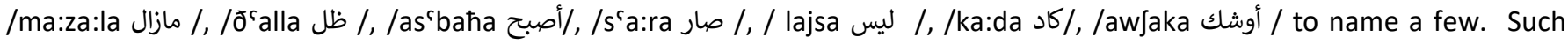
verbal particles play an important role in producing/adding new tense /aspect forms when attached to the primary form of the verb. Several scholars have studied the functions of these grammatical units that cannot be discussed here in this paper due to limited space. However, for the sake of having an idea, let us focus on the particles /qad قد /and /laqad لقد/.

The literature specific to the particle /qad قد/alone is rich and a lot has been said about this small grammatical unit of the Arabic language. Arab grammarians show that /qad قد/ indicates three elements: realization, nearness, and expectation 
(Rachid, 2008: 106) and it can be used with both /al-ma:d` $i: /(T h e$ perfect) and with /al-mud`a:riৎ/ (The imperfect). With the perfect, it indicates realization and stability (the action has already happened) as in:

1. قد سافر زهير

[zuhajr sa:fara (v.perf.) qad (particle)]

Zouhair has traveled.

2.

[al-qamar d`ahara (v.perf.) qad (particle)]

The moon has appeared. (The moon can be seen now.)

Notice that the form /qad+perfect/ in the examples above is used as an equivalent to the present perfect form in English. As we know, one of the functions of the present perfect tense/aspect in English is to refer to a complete action whose result can still be seen in the present time (resultative perfect). The form /qad قد /also indicates nearness (near past) when used with the perfect. It shows that the action has just finished in the recent past as in:

2. قد غادر للتو

[littawi ya:dara (v.perf.) qad (particle)]

He has just left.

As we notice, the present perfect in English is the most appropriate tense to use to refer to finished actions that happened in the recent past. Cantarino (1974) says that /qad/"emphasizes the verbal action in its past value, as having been completed at the moment of speaking or just prior to the introduction of a new situation". However, when used with the particle /ka:na / as in / qad ka:na قد كان /or /ka:na qad كان قد /, it indicates distant past (El Mansouri, 2002: 46; A-ssamerai,1983: 29). With /al-muda:riৎ/ (the imperfect), it expresses expectation and probability (future time) as in:

3. قد يسافر زهير

[zuhajr jusa:firu (v.imperf.) qad (particle)]

Zouhair may travel.

4. قد تمطر في المساء

[al-masa:? fi tumt ${ }^{\text {`iru }}$ (v.imperf. $+3^{\text {rd }}$. pers.sing-it) qad]

It might rain this evening.

Notice that the sentences in English also indicate probability and expectation, and modals like may/might indicate future time. Backley (2004: 551) summarizes the functions of / qad/ by saying that it"is used to indicate an earlier past time when the context already refers to the past. It gives the meaning of the English past perfect/pluperfect" [...], "may correspond to the present perfect" [...], but occasionally "is used simply to stress that the action expressed by the past verb has occurred."

As for/laqad لقد/ which is a cognate of /qad قد/, it is used only with the perfect form, and it indicates emphasis and stability (It emphasizes the completion of the action) as in:

5. لقد غربت الشمس

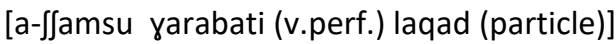

The sun has set.

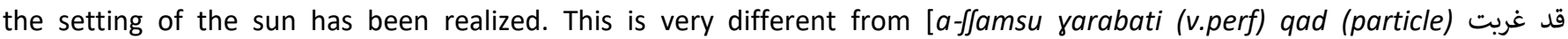
[الشمس],which can either communicate the same meaning as in the previous example, or it can signify that the setting of the sun is expected to happen. For more details, see Bahloul (2008) on qad, fa-qad, wa-qad, and la-qad. Based on the above, it is obvious that studying these two small units alone is really demanding. Most importantly, their important role, as particles, in marking event / time distinctions in the Arabic language is very crucial.

\subsection{Gaps in translating tense and aspect across Standard Arabic and English}

Gaps and problems in translation are likely to exist between English and Arabic due to a number of points. Gaddala (2006: 51) explains that there are, on one hand, more grammatical categories for tense in English than in Arabic. Therefore, one needs 
to be very specific while dealing with this variance. On the other hand, Arabic verb forms can be translated by the means of several English tenses/aspects. Another challenge that faces the translator of Arabic forms is that they do not need to emphasize the verb form itself, but they need to consider other elements in the utterance such as the particles and the contextual clues that contribute to the make-up of the whole temporal construction. Any failure to do so is likely to lead to translation inaccuracy. Shamaa (1978) already tackled this point before by claiming that:

temporal contrasts in Arabic are less systematic, i.e., they are not clearly marked by verb-forms.... temporal reference in Arabic is expressed by means of verb forms in conjunction with time adverbials and other lexical items. It is, however, the context which...finally places the action or event in its true temporal and aspectual perspective. But since context may not provide the same clear-cut and easy determinations afforded by some European [e.g. English] tense systems, it is therefore a source of occasional ambiguity. (Shamaa 1978:32-3)

Verbal particles, adverbials, contextual clues in general do play an important role in the Arabic temporal constructions. They are, in fact, the elements that tell us more about the nature and the time distinctions of each eventuality/action. Thus, the Arabic-English translator must consider all the aspectual clues and references in the source text. They need to recognize whether the actions are complete, in progress, habitual, momentary, instantaneous and so and so forth. These elements can be provided by the context and / or can be found embedded in the particles that usually accompany the verb in Arabic. This of course helps the translator choose the most appropriate equivalent form in the English language.

Another problem in translating across English and Arabic is that most of the English translations of the Arabic forms are characterized by an overuse of the bare perfect and the bare imperfect forms without any particles. Translating this way is regarded as too simplistic and risky. This might happen due to a failure to recognize the other contextual elements that the utterance consists of and a failure to know the exact meaning of the verbal particle/s in the construction. The same thing happens in the reverse case.

\section{Previous studies about ways of bridging the tense gap between English and Arabic}

Several linguists, mainly Arabs, have tried in their studies to discuss possible ways of bridging the tense gap between English and Arabic. Aziz (1989) and Gadalla (2017) among few others are examples of such researchers who tackled this in English. Other studies, in the Arabic language, have also contributed a great deal in providing more clarifications about what translators should consider. Examples of these studies are [السامرائي] A-ssamerai (2003),[مام]Tammam (1994; 2006), to name a few. Tammam (1994), for instance, has suggested examples of Arabic forms along with their functions regarding time, tense, and aspect. Let us observe table 1 below (Translation is mine).

\begin{tabular}{|c|c|}
\hline Tense/aspect & Form \\
\hline Completed distant past & /qad/+imperfect (qad jafৎal) \\
\hline Completed near past & /ka:na/+/qad/+perfect (ka:na qad faSal) \\
\hline Repeated past & /ka:na/+imperfect (ka:na jafৎal) \\
\hline Past action finished in the present & /qad/+perfect (qad faSal) \\
\hline Past action connected to the present & /ma:za:la/+imperfect (ma:za:la jafৎal) \\
\hline Progressive past & /ð`ala/+imperfect (ð`ala jafৎal) \\
\hline Simple past & bare perfect (faSal) \\
\hline Approaching past & /ka:da/+ imperfect (ka:da jafৎal) \\
\hline Commencing past & $/ t^{\varsigma}$ afaqa/+imperfect (t`afaqa+ jafৎal) \\
\hline Simple present & bare imperfect (jafৎal) \\
\hline Repeated present & bare imperfect (jaf̧al) \\
\hline Progressive present & bare imperfect (jafৎal) \\
\hline Simple future & bare imperfect (jaf̧al) \\
\hline Near future & /sa-/ +imperfect ( sa-+jafৎal) \\
\hline Distant future & /sawfa-/ + imperfect ( sawfa- + jafৎal) \\
\hline Progressive future & /sa-/ + jad`allu+ imperfect (sa- +jað`allu+ jafৎal) \\
\hline
\end{tabular}

Table 1: Arabic forms and their functions as suggested by Tammam (1994: 61, 64) 
Similarly, Gaddala (2006) also suggests different Arabic forms that can be used in specific contexts. Let us observe table 2 below.

\begin{tabular}{|l|l|}
\hline \multicolumn{1}{|c|}{ Tense /aspect } & \multicolumn{1}{c|}{ Arabic form } \\
\hline Simple Past & bare perfect form of the verb \\
\hline Near Past & /qad, laqad/ + perfect \\
\hline Distant Past & /kaana/, /kaana qad/ or /qad kaana/ +perfect \\
\hline Progressive Past & /Zalla/ or /kaana/ + imperfect \\
\hline Approaching Past & /kaada/ or /?awšaka/ + (?an) +imperfect \\
\hline Futuristic Past & by /kaana/ + /sa-/ + imperfect \\
\hline Simple Present & the imperfect form of the verb \\
\hline Progressive Present & /ya-Zall-u/ + imperfect \\
\hline Approaching Present & /ya-kaad-u/ or /yuušik-u/ + (?an) +imperfect \\
\hline Commencing Present & /?axad-a/, /šara3-a/, /ja3al-a/ or/?anša?-a/ imperfect \\
\hline Progressive Composite & /maa zaal-a/ or /laa ya-zaal-u/ + imperfect \\
\hline Near Future & / sa-/ + imperfect \\
\hline Distant future & /sawfa/+ imperfect \\
\hline Progressive Future & /sa-, sawfa/ + /ya-Zall-u/ +imperfect \\
\hline
\end{tabular}

Table 2: Possible Arabic forms by the means of particles as suggested by Gadalla (2006: 244)

As we have seen, there are some slight differences between Tammam's and Gadalla's models. Yet, they are not contradicting each other. They, in fact, complement each other in the sense that we can combine the two representations together. We can also add more verbal particles to both representations. Most importantly, both representations have emphasized the fact that verbal particles and prefixes are very important to the whole make-up of the temporal distinctions in the Arabic language. The bare perfect and the bare imperfect forms alone are not enough to mark all those distinctions.

\section{Extensive ways of bridging tense gap in English-Arabic translation}

Based on our previous discussion and our research in general, we provide, in this section, a synopsis about the possible ways of bridging the tense gap in English-Arabic translation. More precisely, our focus will be on how the 12 English tenses along with their different functions can be translated into Arabic. Here, in this section, we confirm the fact that some of the English tenses/aspects can be rendered into Arabic by the means of the bare perfect, or the bare imperfect forms alone and that others are realized by the means of a combination of one of these forms together with particles and/or prefixes. We also emphasize the fact that some event structures in English can be translated into Arabic by using both the bare perfect and/or the bare imperfect forms along with particles giving the translator two options.

\subsection{Ways of translating the simple present tense/aspect into Arabic}

Generally, the English simple present is usually rendered into Standard Arabic by means of the bare imperfect form / ?afৎal (أفعلت /is also used as demonstrated by the examples in (1.7.) below.

\subsubsection{Present simple for permanent states}

- I live in London. أعيش في لندن.

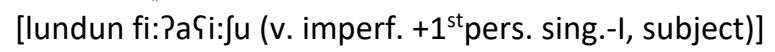

- Ahmed works in a bank.

يعمل أحمد في بنك.

[bank fi: ?aћmadu jaSmalu (v.imperf.)] 


\subsubsection{Present simple for repeated actions}

- I visit my relatives every Saturday. أزورأقاربي كل يوم سبت.

[sabt jawmi kola Paqa:ribi Pazu:ru (v.imperf. $+1^{\text {st }}$ pers.sing-I, subject)]

- Sarah goes to school everyday.

تذهب سارة الى المدرسة كل يوم.

[jawm kolla al-madrasa ila: sa:ra tadhabu (v.imperf.)]

\subsubsection{Present simple for facts and general truths}

- The sun rises in the east.

تشرق الشمس من المشرق.

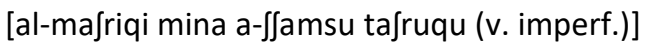

- Water boils at $100^{\circ}$ Celecus.

يغلي الماء على حرارة 100 درجة.

[daraza 100 hara:rat ؟ala: al-ma:?u jayli: (v. imperf.)]

\subsubsection{Present simple for habitual situations (habits)}

- Women in Morocco prepare the most delicious types of sweets during Ramadan.

تجهز النساء في المغرب ألذ أنواع الحلويات خلال شهر رمضان.

[Ramada:n Jahri xila:la al-ћalawija:t ?anwa:Si ?alađđa al-mayribi fi: a-nnisa:?u

tuzahhizu (v. imperf.)

- Americans celebrate Independence Day on July $4^{\text {th }}$.

يحتفل الأمريكان بعيد الاستقلال في الرابع من يوليوز.

[julju:z min a-rra:biৎi fi al-istiqla:I biৎi:di al-amrika:n jaћtafilu (v. imperf.)]

\subsubsection{Present simple: instantaneous use, especially in formal speech, sport commentaries, and demonstrations}

- I declare the meeting open.

أعلن افتتاح الجلسة.

[al-zalsa iftita:ha ?uৎlinu (v. imperf. $+1^{\text {st }}$. pers. sing.-I, subject)]

- Ronaldo scores his second goal!

يسجل رونالدو هدفه الثاني.

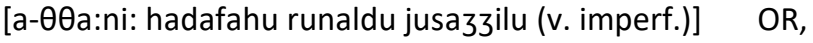

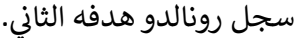

[a- $\theta \theta a: n i$ hadafahu runaldu sazzala (v. perf.)

Notice that in the second example, the bare perfect form /sazzala/ (scored) is also possible in Arabic.

\subsubsection{Present simple for fixed future arrangements}

- The plane takes off at seven.

تقلع الطائرة على الساعة السابعة.

[a-ssa:bi؟a a-ssa:؟a ؟ala a-t`a:Piratu tuqliৎu (v. imperf.)]

Also,

ستقلع الطائرة على الساعة السابعة.

[a-ssa:bi؟a a-ssa:؟a ؟ala a-t`a:Piratu sa-tuqliৎu (/sa- /+v. imperf.)]

Notice that the prefix /sa-/ is attached to the imperfect form to refer to a future action. This is, in fact, the most commonly used form, along with the prefix /sawfa-/+ the imperfect, in the Arabic language when the context involves the future. 


\subsubsection{Present simple with verbs of communication (hear, tell, inform...etc)}

- I hear you're going to buy a new car.

سمعت أنك ستشتري سيارة جديدة.

[3adi:da saja:ra sa-taftari: Pannaka samiStu (v.perf.+1st. pers.sing-I, subject)]

- They tell me you've just been to Greece.

أخبروني أنك كنت للتو في اليونان.

[al-juna:n fi: littawi kunta Pannaka Paxbaru:ni:(v.perf.+1 ${ }^{\text {st }}$. pers.sing-I, subject)]

Notice that in the statements above, the perfect form of the verb is used in both examples. The use of the imperfect is totally inaccurate in Arabic. Thus, the use of the present must be seen as an exception in English since this language may also use the past form, like the case in Arabic, to describe the actions above e.g. 'I heard you're going to buy a new car' and 'they told me you've just been to Greece'.

\subsubsection{Present simple for urgency as in news headlines}

- The council discusses the impact of Covid-19 pandemic on the European economy. يناقش المجلس تأتير جائحة كوفيد 19 على الاقتصاد الأوروبي.

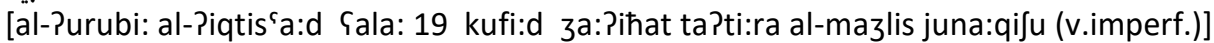

In short, the English present simple is one of the structures that can be easily translated into Arabic since in most cases, if not all, the bare imperfect is the most appropriate form to be used.

\subsection{Ways of translating the present progressive into Arabic}

In Standard Arabic, the present progressive is usually rendered by means of the bare imperfect form alone / Paf̧al أفعل/ or

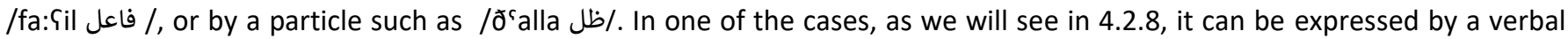
particle in the bare perfect form such as /s`a:ra صار / and /as'baha أصبح/ /

\subsubsection{Present progressive for the moment of speaking or around a period}

- Ahmed is laughing.

أحمد ضاحك.

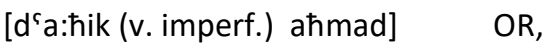

يضحك أحمد.

[aћmad jad`haku (v.imperf.)]

- It is raining at the moment.

تمطر في هاته الأثناء.

[al-Paقna:? ha:tihi fi tumt`iru (v. imperf.+3rd. pers. sing-it, subject)] OR,

الجو ماطر في هاته الأثناء.

[al-PaӨna:? ha:tihi fi ma:t`irun (v.imperf.) al-zawwu]

- Karim is studying history at the university.

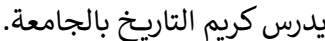

[bilza:mi؟a a-tta:ri:xa kari:mun jadrusu (v. imperf.)]

\subsubsection{Present progressive indicating temporary habits}

- They are smoking a lot these days.

يدخنان كثيرا هذه الأيام.

[al-Paja:m ha:đihi kaӨi:ran judaxxina:ni (v.imperf.+3 ${ }^{\text {rd }}$. pers. Plr. (dual), subject)]

- He is working late every night.

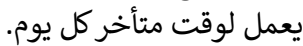


[jawm kulla muta?axir liwaqtin jaSmalu (v.imperf.) OR,

يظل يعمل لوقت متأخر كل يوم.

[jawm kulla mutaPaxir liwaqtin jaৎmalu (v.imperf.+3rd.pers.sing-he,subject) jað`allu (particle, imperf.)]

\subsubsection{Present progressive for actions happening before or after a given time}

- We are usually having lunch at one o'clock.

غالبا ما نتناول وجبة الغذاء على الساعة الواحدة.

[al-wa:hida a-ssa:ৎa Sala al-yađa:?i wazbata natana:walu (v.imperf.+1st. pers. plr. We,

subject) ma: ya:liban]

\subsubsection{Present Progressive for annoying habits}

- She is forever being late.

تأتي دوما متأخرة.

[muta?axxira dawman ta?ti: (v.imperf.+ 3rd. pers. sing.-she, subject)]

- He is always losing his keys.

دائما ما يضيع مفاتيحه.

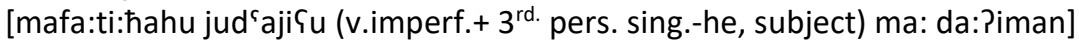

\section{4..25. Present progressive for actions that happen again and again with no change}

- It is always raining in London.

دوما ما تمطر في لندن

[lundun fi tumt ${ }^{c}$ iru (v.imperf. $+3^{\text {rd }}$. pers. sing.- it, subject) ma: dawman]

- I like him because he is always laughing.

يعجبني لأنه دوما يضحك.

[jad`hak (v.imperf.+ $3^{\text {rd }}$. pers. sing.-he, subject) dawman li?annahu juSjibuni]

\subsubsection{Present progressive for future arrangements}

- I'm visiting my friend in Dubai next December.

سأزور صديقي في دبي شهر دجنبر المقبل.

[al-muqbil duzanbir Jahra dubaj fi s`adi:qi sa-Pazu :ru (/sa-/ +v. imperf.+ $1^{\text {st }}$ pers. sing.-I, subject)]

- They are going for a picnic next Sunday.

سيذهبون في نزهة الأحد المقبل.

[al-muqbil al-Paћada nuzhatin fi sa-jadhabu:na (/sa-/+v.imperf.+3rd. pers. plr.-They, subject)]

\subsubsection{Present progressive for changing, growing/developing situations}

- The climate is changing rapidly.

يتغير الجو بسرعة.

[bisurSa alzawwu jatayajaru (v. imperf.)] OR,

- يظل الجو يتغير بسرعة

[bisurৎa jatayajaru (v.imperf.) alzawwu jað`allu (particle, imperf.)]

- I'm getting better at playing the piano.

أظل أتحسن في عزف البيانو.

[al-bijanu ؟azfifi: ataћassanu (v.imperf.+1st. pers. sing.-I, subject) að`allu (particle, imperf.)] 


\subsubsection{Present progressive for new states / current trends}

- What sorts of clothes are teenagers wearing nowadays?

أي نوع من الألبسة يرتديها المراهقون في وقتنا الحالي؟

[al-ha:li waqtina fi: al-mura:hiquna jartadi:ha: (v.imperf.) al-albisa mina naw

- People are becoming vegetarian more and more.

صار الناس نباتيين أكتر فأكتر.

[faPaktar aktara naba:tji:na a-nna:su s`a:ra (v. particle. perf.)] OR, أصبح الناس نباتيين أكتر فأكتر.

[fa?aktar aktara naba:tji:na a-nna:su Pas'baha (v.particle. perf.)]

Notice that in the case of the particle /ð`alla/ realized by /jað‘allu/ and /að‘allu/ in the second and the third examples in 4.2.7 is used in the imperfect form together with another imperfect verb whereas particles such as $/ s^{\varsigma} a: r a /$ and $/ \operatorname{Ras}^{\varsigma} \mathrm{baha} /$ in the second example in 4.2.8. are used alone in the perfect form.

\section{Ways of translating the present perfect into Arabic}

The present perfect can be rendered into Arabic by the use of the particle /qad/ or /laqad/ + the perfect form of the verb (qad faSal قد فعل or laqad faSal لقد فعل). As mentioned before, the use of /qad/ indicates that the action occurred in the near past whereas /laqad/ is used for emphasis. Sometimes the bare perfect form alone (fa\}al فعل is also used to describe eventualities in the English present perfect as in example 4.3.1. below.

\subsubsection{Continuative perfect}

- I have lived in this house for 10 years.

سكنت بهذا المنزل عشرة أعوام.

[?aৎwa:m \aJrata al-manzili biha:đa sakantu (v.perf.+1st. pers. sing.-I, subject)]

\subsubsection{Perfect of recent past}

- I have just finished my work.

لقد /قد أنهيت عملي للتو.

[littawi Samali ?anhajtu (v. perf.+1st. pers. sing-l, subject)+ qad / laqad (particle)]

- The train has arrived.

لقد وصل القطار.

[al-qit`a:r was`ala (v. perf.)+ laqad (particle)] OR,

وصل القطار.

[al-qit`a:r was`ala (v. perf.)]

\subsubsection{Experiential perfect}

- I have read this book several times.

لق لقد قرأت هذا الكتاب مرات عدة.

[Sida marra:tin al-kitaba ha:đa qara?tu (v.perf.+1st. pers. sing-l, subject) laqad (particle)]

قرأت هذا الكتاب العديد من المرات.

[al-marra:t mina al-؟adi:daal-kita:ba ha:đa qara?tu (v.perf.+ 1st. pers. sing-I, subject)]

- I have visited Paris three times before.

زرت باريس ثلاث مرات من قبل.

[qabl min marra:tin Oala:Oa ba:ri:s zurtu (v. perf.+ 1st. pers. sing-l, subject)] OR,

- لقد زرت باريس ثلاث مرات من قبل

[qabl min marra:tin Өala:Өa ba:ri:s zurtu (v. perf.+ 1st. pers. sing-I, subject)+ laqad (particle)]

\subsubsection{Perfect of result (action in the past/ result in the present)}

- I have lost my sunglasses.

قد/لقد أضعت نظاراتي الشمسية. 


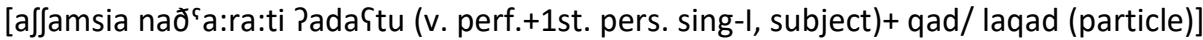

- He has graduated from university.

لقد تخرج من الجامعة.

[al-ja:miৎa mina taxarraza (v. perf.+ $3^{\text {rd }}$. pers. sing-he, subject)+ laqad (particle)]

\subsection{Ways of translating the present perfect progressive into Arabic}

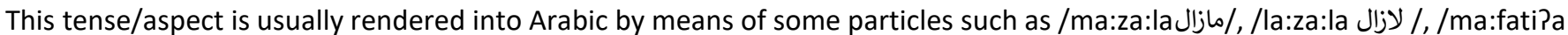
/مافئ/....etc + ma:bariha the imperfect form of the verb. These particles indicate durativity/continuity of the action.

\subsubsection{Present perfect progressive for duration / continuity}

- I have been waiting for the bus since 9 o'clock.

لازلت / ما زلت أنتظر قدوم الحافلة منذ الساعة التاسعة.

[a-tta:siৎa a-ssa:؟a munðu al-ћa:fila qudu:ma Pantað`iru (v. imperf.+1st. pers. sing-I, subject) + ma:ziltu/ la:ziltu (particle)]

- He has been working seriously.

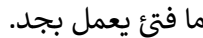

[bijid jaSmalu (v. imperf.+ 3rd. pers.sing-he, subject)+ ma:fati?a (particle)]

\subsubsection{Present perfect progressive for limited duration}

- She has been attending classes regularly.

لا زالت تحضر الحصص بانتظام.

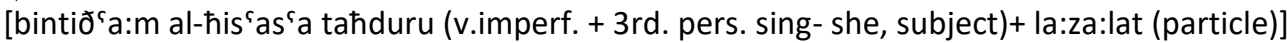

- The boy has been crying.

ما برح الولد يبكي.

[jabki: (v.imperf. + 3rd. pers. sing-he, subject) al-waladu ma:bariћa(particle)]

\subsubsection{Present perfect progressive for series of durative repeated separate actions}

- He has been phoning me all week.

ظل يهاتفني الأسبوع بأكمله.

[bi?akmalih al-Pusbu:؟a juha:tifuni(v.imperf.+3rd. pers. sing-he, subject)+ð`alla (particle)]

OR,

ما انفك يهاتفني الأسبوع بأكمله.

[bißakmalih al-?usbu:؟a juha:tifuni (v.imperf.+3rd. pers. sing-he, subject)+manfakka (particle)]

- The university has been sending students here for training.

دامت الجامعة ترسل طلبتها الى هنا لعقود من أجل التداريب

[a-ttada:ri:b azli min liৎuqu:din huna:ila: talabataha: tursilu (v.imperf.) al-za:miৎatu da:mati (particle)]

OR,

لا زالت الجامعة ترسل طلبتها الى هنا من أجل التداريب.

[a-ttada:ri:b azli min liৎuqu:din huna: ila: talabataha tursilu (v.imperf.) al-za:miৎatu la:za:lati (particle)]

\subsection{Ways of translating the simple past into Arabic}

The simple past tense is rendered into Arabic by means of the bare perfect form of the verb. The particles /ka:na+qad/ or /qad+ka:na/ are attached to the bare perfect form to indicate distant past. Additionally, the form /ka:na/+ the imperfect form of the verb is usually used to refer to past habits, though the bare perfect form along with the existence of an adverbial can also express this meaning as in the third sentence in the example 5.3 below. When a form like /ka:na/+ the imperfect is used, it indicates future in the past. 


\subsubsection{Completed / distant past actions}

- Christopher Columbus discovered America in 1492.

اكتشف كريستوفر كولومبوس أمريكا سنة 1492.

[1492 sanata Pamri:ka kulumbus krist`ufar Piktajafa (v. perf.)] OR,

كان كريستوفر كولومبوس قد اكتشف أمريكا سنة 1492 (pa

[1492 sanata Pamri:ka Piktajafa (v. perf.) qad (particle)kulumbus krist` ${ }^{\varsigma} u f a r$ ka:na (particle)]

\subsubsection{Simple past for durative but completed actions}

- I lived in Cairo for two years.

عشت بالقاهرة لسنتين.

[lisanatajni bilqa:hira Siftu (v.perf. $+1^{\text {st }}$ pers.sing-I, subject)] OR,

كنت قد عشت بالقاهرة لسنتين.

[lisanatajni bilqa:hira Siftu (v.perf. $+1^{\text {st }}$ pers.sing-l, subject) qad (particle)+ kuntu (particle)]

\subsubsection{Simple past for narration / series of completed actions}

- Last night, I heard a strange noise. I wondered what that was. I took my arm and I went downstairs. I couldn't see anything. I waited for few seconds. Then, I switched on the light, and I found that it was just the cat playing with the milk pot.

$$
\begin{aligned}
& \text { ليلة أمس سمعت صوتا غريبا فتساءلت ماكان ذلك الصوت. حملت سلاحي ثم نزلت الى الطابق السفلي. لم أستطع رؤية أي شيء، فانتظرت لبضع } \\
& \text { ثوان ثم أشعلت النور فوجدت فقط القطة تلعب بإناء الحليب. }
\end{aligned}
$$

All past verbs in this short paragraph are rendered by means of the bare perfect form in Arabic.

\subsubsection{Simple past for habits or facts that no longer exist (not valid anymore)}

- As a child, he always stole chocolate.

حين كان طفلا كان دوما يسرق الشكولاتة

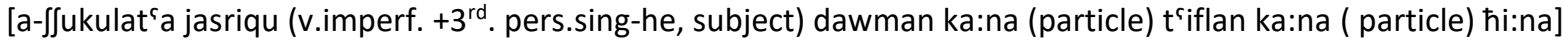

$\mathrm{OR}$,

- وهو طفل كان دوما يسرق الشكولاتة.

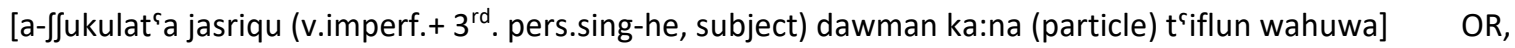

- لطالما سرق الشكولاتة عندما كان طفلا

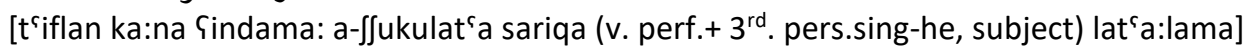

\subsubsection{Future in the past}

- I knew they would come late to the party.

علمت أنهم كانوا سيتأخرون عن الحفل.

[l-ћafl ৎani /sa-/+ jata?axaru:na (v. imperf. +3rd. pers. plr-They) ka:nu: (particle) Pannahum Salimtu (v.perf.+ 1st. pers. sing-l, subject)

- I informed the family that he was going to arrive on Monday.

أخبرت العائلة أنه كان سيصل يوم الاثنين.

[al-PiӨnajn jawma/sa-/+ jas'ilu (v. imperf.+3 ${ }^{\text {rd }}$. pers. sing-he) ka:na (particle) Pannahu Paxbartu (v. perf.+ $1^{\text {st }}$. pers. sing- I, subject)]al-\{a:Pila

\subsubsection{Simple past in reported speech}

- Sarah said (that) she liked the food in Morocco.

قالت سارة أنها أحبت الأكل في المغرب.

[al-mayrib fi: al-Pakla ?ahabbat (v.perf.) annaha: sa:ra qa:lat (v. perf.)] 


\subsubsection{Unreal present situations through the use of simple past.}

- I wish I succeeded last year.

ليثني نجحت السنة الفارطة

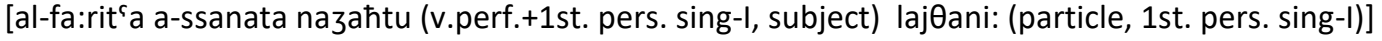

- If I had money, I would help the poor.

لوكان لدي مال لساعدت الفقراء.

[al-fuqara:? la-sa:\{adtu (v. perf. $+1^{\text {st }}$. pers. sing-l, subject) ma:I ladaja ka:na (particle) law]

\subsection{Ways of translating the past progressive into Arabic}

The past progressive is usually rendered into Arabic by means of the particle /ka:na $6 /+$ the imperfect form of the verb. Sometimes the particle /ð`alla ظل/ is used instead of /ka:na كان/.

\subsubsection{Past progressive describing background or atmosphere (what was going on when something happened)}

- I was listening to music when they were arguing.

كنت أستمع الى الموسيقى عندما كانا يتشاجران.

[jatafa:zara:ni (v.imperf.+3rd. pers.plr-they, subject) ka:na: (particle) Sindama: al-musi:qa: ila: astamiৎu

(v.imperf.+1st. pers.sing-I, subject) kuntu (particle)]

- When I walked into the office, several people were busily typing, some were talking on the phone, the boss was yelling directions, and customers were waiting to be helped.

حينما دخلت المي الإدارة كان مجموعة من الموظفين منشغلين بالكتابة على حواسيبهم. وكان آخرون يتحدثون عبر الهاتف وكان رب العمل يعطي تعليماته وكان/ظل الزيناء ينتظرون أن تمد لهم يد المساعدة.

All verbs in the Arabic translation are written by means of the particle /ka:na/+ the imperfect form of the verb. Yet, the particle / J'alla/ can also be used instead of / ka:na/ as indicated by the last verb in the Arabic translation:

- Customers were waiting to be helped.

ظل الزيناء ينتظرون أن تمد لهم يد المساعدة.

[al-musa:Yada jada lahum tumadda an jantað`iru:na (v.imperf.)a-zzubana:? đ’alla

(particle)]

\subsubsection{Past progressive for annoying, irritating, or shocking past habits}

- She was constantly coming to class late.

دوما ما كانت تصل للفصل متأخرة.

[muta?axira lilfasli tas ${ }^{\varsigma}$ ilu (v.imperf.+3rd. pers. sing-she, subject) ka:nat (particle) ma: dawman]

- They were always complaining.

كانا يتشاجران باستمرار.

[bistimra:r jataja:zara:ni(v. imperf.+3 ${ }^{\text {rd }}$. pers. plr. (dual), subject) ka:na:(particle)]

\subsection{Ways of translating the past perfect into Arabic}

The past perfect is usually rendered into Arabic by means of the particles /ka:na/+/qad/+ the perfect form of the verb. Sometimes the bare perfect alone can be used in some cases. In some statements with negation, the construction /lam/+ /ka:na/+ /qad/+ the perfect form of the verb is used.

\subsubsection{Past perfect for an action that occurred before another action of the past}

- I took a long nap because I had eaten a lot at lunch.

أخدت قيلولة مطولة لأني كنت قد أفرطت في الأكل أثناء الغذاء.

[al-yađa:? aӨna:?a al-Pakli fi Pafrat'tu (v. perf.+ 1st. pers. sing-l, subject) qad (particle) kuntu (particle) li?anni mut'awwala qajlu:latan Paxađtu (v. perf.+ 1st. pers. sing-l, subject)]

- I had met Robert before I met John.

التقيت روبرت بعد أن كنت قد التقيت جون قبله.

[qablah zu:n Piltaqajtu (v.perf.+ 1st. pers. sing-I, subject) qad (particle) kuntu (particle) an ba९da 
ru:birt iltaqajtu (v.perf. + 1st. pers. sing-I, subject)]

\subsubsection{Past perfect for actions occurred before a specific time in the past}

- I had finished my work by 5 p.m.

كنت قد أنهيت عملي قبل الساعة الخامسة مساءا.

[masa:?anal-xa:misa a-ssa:؟a qabla Yamali: ?anhajtu (v. perf.+1st. pers. sing-I, subject)

qad (particle) kuntu (particle)] OR,

أنهيت عملي قبل الساعة الخامسة مساءا.

[masa:?anal-xa:misa a-ssa:\{a qabla Yamali: Panhajtu (v. perf.+1st. pers. sing-I, subject)]

\subsubsection{Past perfect indicating experience or lack of experience}

- I had already read that book when John told me about it. (Experience)

كنت قد قرأت ذلك الكتاب قبل أن يحدثني جون عنه.

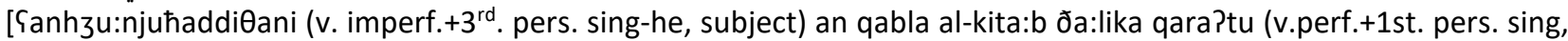
subject) qad (particle) kuntu (particle)]

- She had never been to Opera before last night. (Lack of experience)

لم يسبق لها أن حضرت حفل الأوبرا قبل ليلة أمس.

[?amsin lajlata qabla al-?ubra: hafla had`arat (v. perf.+3rd. pers. sing-she) an laha:jasbiq lam] OR,

. لم تحضر حفل الأوبرا قط قبل ليلة أمس

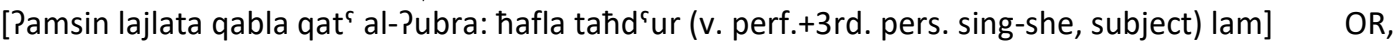

لم تكن قد حضرت حفل أوبرا قبل ليلة أمس.

[?amsin lajlata qabla ?ubra: hafla ћad`arat (v. perf.+3rd. pers. sing-she, subject) qad (particle) takun (particle)lam]

\subsubsection{Past perfect in reported speech statements and conditional sentences}

- The nurse said that the patient had died before the doctor's arrival.

قالت الممرضة بأن المريض كان قد توفي قبل وصول الطبيب.

[a-t't $t^{\varsigma}$ abi:b wusu:li qabla tuwuffija (v.perf.+3rd. pers. sing-he) qad (particle) ka:na (particle) al-mari:d`a bi-?anna almumarrid'atu qa:lati (v. perf.)] OR,

- قالت الممرضة بأن المريض توفي قبل وصول الطبييب.

a-t` $t^{\varsigma}$ abi:b wusu:li qabla tuwuffija (v.perf.+3rd. pers. sing-he) al-mari:d`a bi-Panna al-mumarrid`atu qa:lati (v. perf.)

\subsubsection{Past perfect indicating possible conditions in the past}

- If I had known you arrived yesterday, I would have come to see you.

لو كنت علمت أنك وصلت البارحة، لكنت قد جئت لرؤيتك.

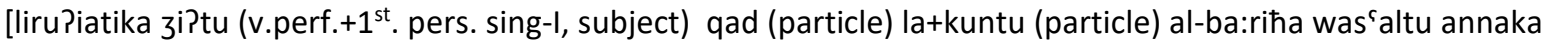

Palimtu (v. perf. $+1^{\text {st }}$ pers. sing-l) kuntu (particle) law]

- I wouldn't have had such accident if I had driven carefully.

لم أكن لأقوم بحادث سير لوكنت قد سقت بحذر.

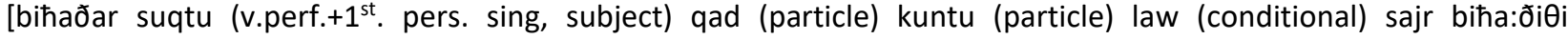
li+?aqu:ma (v. perf. $+1^{\text {st }}$ pers. sing-I) ?akun (particle) lam

\subsection{Ways of translating the past perfect progressive into Arabic}

The past perfect progressive is usually rendered into Arabic by means of the particle /ka:na / + the imperfect form of the verb. This construction shows the continuity of the action. It is usually compared to the construction /ka:na/+ /qad/+ the perfect form of the verb that emphasizes the completion of the action.

\subsubsection{Past perfect progressive indicating duration}

- She had been talking on the phone for an hour when John arrived.

$$
\text { كانت تتحدث عبر الهاتف لساعة من الزمن حين وصل جون. }
$$




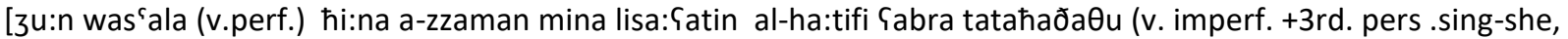
subject) ka:nat (particle)]

- I had been writing my diary when the clock struck midnight.

كنت أكتب مذكراتي عند ما أشارة الساعة الى منتصف الليل.

[a-llajli muntas`afi ila: a-ssa:ৎatu ?aja:rati ९indama: muðakara:ti: ?aktubu (v. imperf.+1 ${ }^{\text {st }}$. pers.sing-l, subject) kuntu (particle)]

\subsection{Ways of translating the simple future into Arabic}

The simple future is rendered in Arabic by means of the prefixes /sa-/ or /sawfa/ + the imperfect form of the verb. The prefix /sa-/ shows that the action will happen in the near future whereas /sawfa/ indicates distant future. Yet, it is very important to notice that in most cases language users do not distinguish between both of them.

\subsubsection{Simple future indicating intention, instant decision, promise, certainty, suggestion, and prediction (future time)}

- I will go to London next week. (instant decision)

سأذهب الى لندن الأسبوع القادم.

[al-qa:dim al-?usbu:\{alundun ila sa- (prefix)+ Padhabu (v. imperf.1st. pers. sing-I, subject) ]

- I will help you. Don't worry! (promise)

سوف/سأساعدك. لا تقلق.

[taqlaq la: sawfa-(prefix)/sa-(prefix)+?usa:Yiduka (v. imperf.1st. pers. sing- I, subject)]

- We shall need more budget for our project. (certainty)

سوف نحتاج ميزانية أكبر لمشروعنا.

[limafru:Sina: akbar miza:nijatan sawfa- (prefix)+ naћta:3u (v. imperf.+1st. pers. plr-we, subject)]

- Shall we move to the front seat? (suggestion)

هلا تقدمنا الى المقعد الأمامي؟

[al-ama:mi al-maq\{adi ila: taqaddamna: (v. imperf.+1 ${ }^{\text {st }}$. pers. plr-we,subject) halla:]

- It will rain tomorrow. (prediction)

ستمطر غذا.

[yađan sa-(prefix) tumt ${ }^{\text {iru }}$ (v. imperf. $+3^{\text {rd }}$. pers. sing-it, subject)

- I'm going to see my mother. (Urgency)

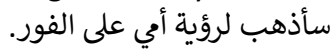

[al-fawr Yala: ?umi: liru?jati sa-(prefix)+?aðhabu (v. imperf.+1st. pers. sing-l, subject)]

- We are going to buy a new car. (intention)

سوف نشتري سيارة جديدة.

[3adi:da saja:ra sawfa-(prefix)+naftari: (v. imperf. $1^{\text {st }}$ pers. plr.-we, subject)]

\subsection{Ways of translating the future progressive into Arabic}

The future progressive is usually rendered into Arabic by means of two different constructions: /sa-/+/að`allu/+ the imperfect form and /sa-/ +/ ?aku:nu/+ the imperfect form of the verb.

\subsubsection{Future progressive for durative future actions}

- We are going to be playing tennis in the club tomorrow morning.

سنظل نلعب التنس طيلة صباح يوم غذ.

[yað jawmi s`aba:ћa t`i:lata a-ttinis nalৎabu (v. imperf.+ $1^{\text {st }}$. pers. plr-we, subject)sa-(prefix)+ nað`allu (particle)]

- I will be watching my favourite sport programme at 6 tonight.

سأكون أشاهد برنامجي الرياضي المفضل الليلة على الساعة السادسة.

[a-ssa:disa assa:؟a ؟ala: a-llajlata al-mufad`al a-rrija:d`ii: barna:mazi: ?ufa:hidu (v. imperf. + 1st. pers. sing-l, subject) sa-(prefix)+ aku:nu (particle)] 


\subsubsection{Future progressive for two separate long actions taking place at an exact time or around a period in the future}

- At 8 p.m, I will be cooking dinner and Sarah will be doing her homework.

$$
\text { في الساعة الثامنة مساءا سأكون أحضر العشاء بينما سارة ستكون تنجز وجباتها المدرسية. }
$$

[al-madrasia wa:ziba:tiha tunjizu (v. imperf+ $3^{\text {rd }}$. pers. sing-she, subject) sa-(prefix)+ taku:nu (particle) sa:ra bajnama: al-

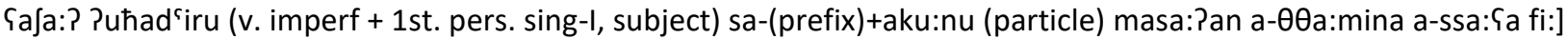

\subsection{Ways of translating the future perfect into Arabic}

The future perfect tense/aspect is usually rendered into Arabic by means of the construction /sa-/+/aku:nu/+ /qad/ + the perfect form of the verb. Sometimes it is possible to do without the prefix /sa-/. A construction like /aku:nu/ +/qad/+ the perfect form is enough to communicate the same meaning as the one indicated by the English future perfect.

\subsubsection{Future perfect for actions / events that will finish just before other actions or before a specific time in the future}

- I will have received my promotion by next December.

$$
\text { سأكون قد حصلت على ترقيتي بحلول شهر دجنبر المقبل. }
$$

[al-muqbil dujanbir Jahri biћulu:li tarqijati: ؟ala: ћas`altu (v. perf.+ 1st. pers. sing-I, subject) qad (particle) sa-(prefix)+ aku:nu (particle)]

- We will have returned home before sunset.

$$
\text { سنكون قد عدنا الى المنزل قبل غروب الشمس. }
$$

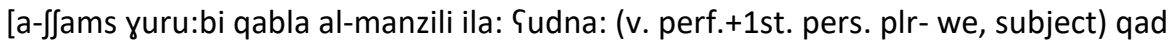

(particle) sa-(prefix)+ naku:nu (particle)]

\subsubsection{Future perfect along with the present simple in time and if-clauses}

- When you come back, I will have cooked dinner.

حين تعود، سأكون قد جضرت وجبة العشاء.

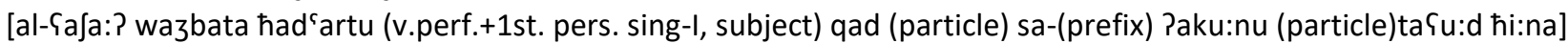
OR,

حين تعود، أكون قد حضرت وجبة العشاء.

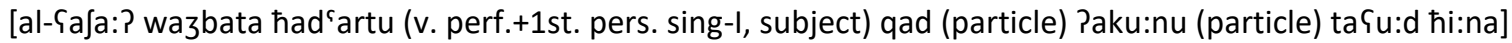

\subsection{Ways of translating the future perfect progressive into Arabic}

Research has shown that there is almost no Arabic verb construction that expresses the same meaning of the English future perfect progressive. Yet, there is a structure suggested by Hassoon, Hameed, and Mahdi (2013:17) which I will adopt here in this paper. The authors suggested the construction: /sa-/ + / Paku:nu/+ the imperfect form /fa:Sil فاعل/. Let us observe the examples below:

- You will have been doing a lot of effort when John arrives.

ستكون قائما بمجهود كبير عندما يصل جون.

[3u:njas`ilu Sindama: kabi:r bimazhu:din qa:?iman (v.imperf. ${ }^{\text {nd }}$ pers. sing-you, subject) sa-(prefix) taku:nu (particle)]

- Sarah will have been studying English for 18 months by the time she gets hercertificate.

ستكون سار ة دارسة الإنجليزية لمدة 18 شهرا أثناء حصولها على شهادتها.

[Jaha:datiha:Sala: hus`u:liha:?aӨna:?aJahran 18 limuddatial-anzali:zia da:risatan (v.

imperf. + 3rd. pers. sing-she, subject) sa:ra sa- (prefix) taku:nu (particle)

This form suggested by Hassoon, Hameed, and Mahdi (2013:17) can be used as an equivalent to the future perfect progressive in English though such use is not that common in the Arabic language.

\section{Conclusion}

Throughout the present paper, we have tried to show that the tense gap between English and Standard Arabic is bridgeable as all the English event structures presented here have been smoothly translated into Arabic. Tense/aspect equivalences do exist between these two distinct languages. As a matter of fact, each language has its own mechanisms by which eventualities are expressed. On one hand, English uses a combination of tense markers along with a set of auxiliaries and verb endings to refer to aspect. Arabic, on the other hand, uses only its two aspectual oppositions 'the perfect' and 'the imperfect' realized by the different [tafYila:t تفعيلات] or verb forms together with a number of verbal particles. In relation to 
this, the present paper highlights two main points: (1) it confirms the fact that the perfect and the imperfect forms in Arabic are not always used to refer to past or present respectively. Their use and functions shifts in discourse and they are sometimes used interchangeably. (2) it emphasizes the fact that verbal particles in Arabic are important and necessary in communicating more complex meanings that cannot be expressed by the aspectual forms alone. Thus, all that the translator needs to do is to pay attention to those mechanisms and means by which eventualities are expressed in each language. While dealing with the Arabic language, the translator also needs to consider other elements beyond the verb construction, mainly grammatical words and contextual clues so as to understand the real function of the whole utterance. This will undoubtedly help them select the most appropriate equivalent form.

\section{References}

[1] Almakhzoumi, M. (1965). On Arabic grammar: criticism and guidance. Beirut:

[2] Assamarai, F, S. (2003). Meanings of grammar. Al-Atik for publishing and distribution.

[3] Assamerai, I. (1983). The verb: it's tense and structures] (3 ${ }^{\text {rd }}$ ed.). Arrisala publishing.

[4] Aziz, Y, Y. (1989). A contrastive grammar of English and Arabic. Mosul: University of Mosul Press.

[5] Bahloul, M. (2008). Structure and function of the Arabic verb. Routledge.

[6] Baker, M. (1992). In other words: a coursebook on translation. London: Routledge.

[7] Bakri, A. (2001). Tense in the wholly Quran: Semantic study of the verbs. House of modern book

[8] Buckley, R. (2004). Modern literary Arabic: a reference grammar. Beirut: Lebanon library.

[9] Cantarino, V. (1974). Syntax of modern Arabic prose. Vol. 1. The simple sentence. Bloomington / London: Indiana University Press.

[10] Comrie, B. (1976). Aspect. Cambridge: Cambridge University Press.

[11] DeCaen, V. (1996). Tenseless languages in light of an aspectual parameter for universal grammar: A preliminary cross-linguistic survey. Toronto Working Papers in Linguistics, 14(2), 41-81.

[12] Downing, A, and Locke, P. (1992). A university course in English grammar. Prentice Hill: International Language Teaching.

[13] Hassoon, H, Hameed, H, and Mahdi, S. (2013). Bridging tense gap in English-Arabictranslation. College of Education and Human Sciences. University of Babylon. Babel, Iraq, pp. 1-21. Retrieved from https://www.researchgate_.net/publication/309126604

[14] El Mansouri, A, J. (2002). Temporal significance in the Arabic sentence] (1 ${ }^{\text {st }}$. ed). The house of culture for publishing and distribution].

[15] Hawamid, Z. (2016). [Temporal constituency of the verb in Surah Yusuf/Chapter 12 Joseph]. MA thesis. Mohamed Boudiaf University.

[16] Gadalla, H, A, H. (2006). Arabic imperfect verbs in translation: a corpus study of Englishrenderings. META: Translators' Journal. V. 51, 51.70. DOI: https://doi.org/10. 7202/012993ar

[17] Gadalla, H, A, H. (2006). Translating English perfect tenses into Arabic: A comparative study of two translations of Pearl Buck's novel 'The Good Earth'. Babel: International Journal of Translation, 52(3), 243 - 26. DOI: 10.1075/ babel. 52.3.03gad

[18] Gadalla, H, A, H. (2017).Translating tenses in English-Arabic and Arabic-English contexts. Cambridge: Cambridge Scholars Publishing.

[19] Ghassemi, L, and Maghsoudi, M. (2015). A study of change of tenses in the process of translation from English into Persian language. Language in India, 15(9):29-39.

[20] Malmkjær, K. (2012). Meaning and Translation. The Oxford Handbook of Translation Studies. Malmkjær K. and Windle, K (ed.). DOI:10.1093/oxfordhb/978019 9239306.013.0009

[21] Nida, E. (1964). Toward a science of translating. Leiden, Netherlands: E. J. Brill.

[22] Nida, E. A, and Taber, C. R. (1982). The theory and practice of translation. Leiden: Brill.

[23] Rachid, K. (2008). Grammatical tense in the Arabic language. The world of culture for publishing and distribution.

[24] Shamaa, N. (1978).A linguistic analysis of some problems of Arabic to English translation [Ph.D. dissertation]. Oxford: Linacre College.

[25] Tammam, H. (1994). Arabic Language: Its meaning and structure] $1^{\text {st }}$ ed).Culture house]

[26] Tammam, H. (2006). Arabic Language: Its meaning and structure (5th ed). The world of books.

[27] Wright, W. (1967). A grammar of the Arabic language (3rd. ed), Vol. 1, Cambridge: CUP

[28] Zhiri, Y. (2014). The translation of tense and aspect from English into Arabic by Moroccan undergraduates: difficulties and solutions. Arab World English Journal, 5(4), 288-296. 